Abstracta Iranica Abstracta Iranica

Revue bibliographique pour le domaine irano-aryen

Volume 31 | 2011

Comptes rendus des publications de 2008

\title{
« Altar shrines and fire altars? Architectural representations on frataraka coinage ». Iranica Antiqua 43, 2008, p. 207-233.
}

\section{Barbara Kaim}

\section{OpenEdition}

1 Journals

\section{Édition électronique}

URL : http://journals.openedition.org/abstractairanica/39485

DOI : 10.4000/abstractairanica.39485

ISSN : 1961-960X

Éditeur :

CNRS (UMR 7528 Mondes iraniens et indiens), Éditions de l'IFRI

\section{Édition imprimée}

Date de publication : 15 mai 2011

ISSN : 0240-8910

Référence électronique

Barbara Kaim, « « Altar shrines and fire altars? Architectural representations on frataraka coinage ». Iranica Antiqua 43, 2008, p. 207-233. », Abstracta Iranica [En ligne], Volume 31 | 2011, document 85, mis en ligne le 15 février 2012, consulté le 05 octobre 2020. URL : http://journals.openedition.org/ abstractairanica/39485; DOI : https://doi.org/10.4000/abstractairanica.39485

Ce document a été généré automatiquement le 5 octobre 2020.

Tous droits réservés 


\section{« Altar shrines and fire altars?} Architectural representations on frataraka coinage ». Iranica Antiqua 43, 2008, p. 207-233.

\section{Barbara Kaim}

L'article est une réaction à la publication de D. Potts dans Iranica Arntiqua 42.2007 où celui-ci admet, comme plusieurs autres chercheurs, que la construction représentée au revers des monnaies des fratarakas est similaire à la «tour » de Naqsh-i Rustam et à celle de Pasargades. Rejetant avec raison cette opinion, les AA. suggèrent d'y voir un monument à l'intérieur duquel se trouvait l'autel du feu en plein air. L'idée dérive de la représentation de sanctuaires grecs et romains, surtout l'Ara Pacis à Rome. La proposition est surprenante mais à première vue seulement. Elle devient intéressante et mérite discussion si on se souvient que nous ne connaissons pas de vestiges des temples du feu ni pour l'époque achéménide (ce qui est en accord avec le récit de Hérodote), ni du temps des fratarakas (le temple éponyme à Persépolis contenait une statue, comme l'a montré P. Callieri, L'archéologie du Fars à l'époque hellénistique, 2007) et si nous nous rappelons les mots de Strabon quand il écrit à propos des mages en Cappadoce «... Ils ont également les Pyraetheia, enclos remarquables, avec un autel au milieu, sur lequel, parmi des monceaux de cendre, brûle le feu éternel entretenu par les mages » (Géographie 15,3,15). 
INDEX

Thèmes : 3.2.3. Séleucides, Parthes et Sassanides

\section{AUTEURS}

BARBARA KAIM

Université de Varsovie 